\title{
Chromosome number variation and evolution in Neotropical Leguminoseae (Mimosoideae) from northeastern Brazil
}

\author{
E.C.X.R. Santos ${ }^{1}$, R. Carvalho ${ }^{2}$, E.M. Almeida ${ }^{1}$ and L.P. Felix ${ }^{1}$ \\ ${ }^{1}$ Programa de Pós-Graduação em Agronomia, \\ Departamento de Ciências Biológicas, Universidade Federal da Paraíba, \\ Areia, PB, Brasil \\ ${ }^{2}$ Departamento de Biologia, Universidade Federal Rural de Pernambuco, \\ Recife, PE, Brasil \\ Corresponding author: L.P. Felix \\ E-mail: 1pfelix@hotmail.com
}

Genet. Mol. Res. 11 (3): 2451-2475 (2012)

Received September 19, 2011

Accepted May 17, 2012

Published June 27, 2012

DOI http://dx.doi.org/10.4238/2012.June.27.1

\begin{abstract}
Most members of the subfamily Mimosoideae have pantropical distributions, variable habits, and a basic chromosome number $x=13$. We examined karyotypic evolution of 27 species of this subfamily occurring principally in northeastern Brazil by examining chromosomes stained with Giemsa. All of the species had semireticulated interphase nuclei and early condensing segments in the proximal region of both chromosome arms. The basic number $x=13$ was the most frequent, with $2 n=2 x=26$ in 19 of the species, followed by $2 n=4 x=52$ and $2 n=6 x=78$. However, the three species of the genus Calliandra had the basic number $x=8$, with $2 n=2 x=16$, while Mimosa cordistipula had $2 n=4 x=32$. The karyotypes were relatively symmetrical, although bimodality was accentuated in some species, some with one or two acrocentric pairs. As a whole, our data support earlier hypotheses that the Mimosoideae subfamily has a basic number of $x=13$ and underwent karyotypic evolution by polyploidy. However, $x=13$ seems to be a secondary basic number that originated from an
\end{abstract}


ancestral stock with $x_{1}=7$, in which polyploidy followed by descending disploidy gave rise to the current lineages with $x=13$. Another lineage, including current representatives of Calliandra with $x=8$, may have arisen by ascending disploidy directly from an ancestral monoploid stock with $x_{1}=7$.

Key words: Mimosoideae; Calliandra; Karyotypic evolution; Polyploidy

\section{INTRODUCTION}

The subfamily Mimosoideae comprises approximately 40 genera and 2500 species distributed throughout tropical, subtropical, and sub-temperate regions (Judd, 2009). The subfamily is divided into 3 tribes: Mimoseae (which includes the former tribes Parkieae and Mimozygantheae), Acacieae, and Ingeae (Luckow, 2005). Some genera of the subfamily have controversial delimitations, such as Acacia sl (one of the largest genera in the subfamily), which is considered polyphyletic; most of the species of northeastern Brazil are included in the genus Senegalia (Queiroz, 2009). The subfamily has significant economic importance: many representatives of the genera Acacia, Albizia, Stryphnodendron, Piptadenia, Enterolobium, Inga, Entada, Parkia, and Prosopis are used as ornamental or forage plants, sources of firewood, or for extracting secondary metabolic compounds.

The subfamily Mimosoideae has only been poorly studied in cytological terms, with chromosome numbers reported for approximately 460 species, corresponding to almost $17 \%$ of the total number of species in the subfamily. These chromosome numbers vary from $2 n=$ 16 in some species to $2 n=208$ in Acacia hebeclada. The most frequent basic number for the group is $x=13$, with polyploidy occurring widely (Atchison, 1951; Dahmer et al., 2011).

Although the subfamily is well-represented in Brazil, only a limited number of chromosomal records are available for this group; the data are even more fragmented for the northeastern region of the country. Only 13 species of the genus Inga were examined by Mata (2009, unpublished data), and all of them had the basic number $x=13$, with the evolution of their chromosome numbers being regulated by various cycles of polyploidy.

The subfamily Mimosoideae is particularly well-represented in northeastern Brazil, with a total of 24 genera and 267 species, most of which occur in the "Caatinga" (dryland) Biome (Queiroz, 2009). Despite the fact that this subfamily has a karyotypic evolution pattern that is apparently preferentially regulated by polyploidy, the occurrence of $x=8$ in the genus Calliandra suggests that a disploidy variation occurred at the very start of the diversification of this group, at least in this lineage (Atchison, 1951).

Certain patterns of karyotypic evolution in plants are influenced by environmental factors. Higher polyploidy frequencies, for example, have been observed among plants growing in the arctic tundra (Brochmann et al., 2004), and among orchids growing on inselbergs in Brazil (Felix and Guerra, 2000). However, this relationship has not been observed in the family Leguminosae or in plants growing in the "Caatinga".

The present study investigated the patterns of karyotypic evolution in different genera of the subfamily Mimosoideae by analyzing the numbers and morphologies of the chromosomes of 27 species belonging to 11 genera of the 3 tribes of Mimosoideae from different Brazilian biomes. Emphasis was placed on the species from the northeastern region of that 
country, principally those from the "Caatinga" region and from altitudinal forests ("Brejos de Altitude"), and the chromosomal variations seen in these 2 environments were comparatively evaluated.

\section{MATERIAL AND METHODS}

Table 1 presents a list of all the species analyzed, their respective chromosome numbers, previous counts, collection sites, and reference specimens. We used root tips from seeds germinated in Petri dishes or excised from plants cultivated in the experimental gardens of the Plant Cytogenetics Laboratory at the Centro de Ciências Agrárias of the Federal University of Paraíba State. Reference specimens of all analyzed materials were deposited in the Jayme Coelho de Moraes Herbarium (EAN).

\begin{tabular}{|c|c|c|c|c|c|}
\hline Taxa & Provenances and biome & Voucher No. & $2 n$ & $\begin{array}{l}\text { Previous } \\
\text { counts }\end{array}$ & Sources* \\
\hline \multicolumn{6}{|l|}{ Tribe Acacieae } \\
\hline Senegalia bahiensis (Benth.) Seigler \& Ebinger & Sertânea, PE (CA) & J.P. Castro, 206 & 26 & - & - \\
\hline S. riparia (Kunth.) Britton \& Rose & Serraria, PB (BE) & E.C.X.R. Santos, 12 & 26 & - & - \\
\hline \multirow[t]{2}{*}{ S. tenuifolia (L.) Britton \& Rose } & Pilões, PB (BE) & E.C.X.R. Santos, 7 & 26 & 26 & A48 \\
\hline & Pilões, PB (BE) & E.C.X.R. Santos, 10 & 26 & & \\
\hline Vachellia farnesiana (L.) Wight \& Arn. & Toritama, PE (CA) & L.P. Felix, S/N & 52 & 52 & A48 \\
\hline \multicolumn{6}{|l|}{ Tribe Ingeae } \\
\hline Abarema filamentosa (Beth.) Pittier. & Morro do Chapéu, BA (CA) & J.P. Castro, 118 & 26 & - & - \\
\hline \multirow[t]{2}{*}{ Calliandra depauperata Benth } & Santa Maria da Boa Vista, PE (CA) & J.P. Castro, 24 & 16 & - & - \\
\hline & Morro do Chapéu, BA (CA) & J.P. Castro, 194 & 26 & - & - \\
\hline C. leptopoda Benth. & Irecê, $\mathrm{BA}(\mathrm{CA})$ & J.P. Castro, 100 & 16 & - & - \\
\hline C. portoricensis (Jacq.) Benth. & Areia, PB (BE) & E.C.X.R. Santos, 16 & 16 & - & - \\
\hline Chloroleucon sp & Serraria, $\mathrm{PB}(\mathrm{BE})$ & E.C.X.R. Santos, 13 & 52 & - & - \\
\hline Enterolobium contortisiliquum (Vell.) Moring. & Juarez Távora, PB (CA) & L.P. Felix, S/N & 26 & 26 & B74 \\
\hline Inga cinnamomea Benth. & Recife, PE (MA) & L.P. Felix, S/N & 26 & - & - \\
\hline \multicolumn{6}{|l|}{ Tribe Ingeae } \\
\hline Inga cinnamomea Benth. & Manaus, $\mathrm{AM}\left(\mathrm{AM}^{*}\right)$ & L.P. Felix, S/N & 26 & - & - \\
\hline I. edulis Mart. & Manaus, $\mathrm{AM}\left(\mathrm{AM}^{*}\right)$ & L.P. Felix, S/N & 26 & 26 & M09 \\
\hline \multicolumn{6}{|l|}{ Tribe Mimoseae } \\
\hline Anadenanthera colubrina (Vell.) Brenan & Caruaru, PE (CA) & L.P. Felix, 13. 146 & 26 & 26 & $\mathrm{O} 10$ \\
\hline \multirow{2}{*}{ Desmanthus pernambucanus (L.) Thell. } & Areia, PB (BE) & E.C.X.R. Santos, 15 & 26 & - & - \\
\hline & Senhor do Bom Fim. BA (CA) & J.P. Castro, 88 & 26 & _- & _- \\
\hline \multirow[t]{2}{*}{ Mimosa arenosa (Willd.) Poir. } & Sertânea, PE (CA) & J.P. Castro, 205 & 26 & - & _- \\
\hline & Areia, PB (BE) & E.C.X.R. Santos, 6 & 26 & - & - \\
\hline \multirow[t]{2}{*}{ M. campicola Harms } & Cuitegí, PB (CA) & L.P. Felix, 13.112 & 78 & 26 & DN11 \\
\hline & Serraria, PB (BA) & E.C.X.R. Santos, 11 & 78 & & \\
\hline M. cordistipula Benth. & Irecê, BA (CA) & J.P. Castro, 97 & 32 & 26 & DN11 \\
\hline M. paraibana Barneby & Lagoa Seca, PB (CA) & L.P. Felix, S/N & 26 & - & - \\
\hline M. pseudosepiaria Harms & Salgueiro, PE (CA) & J.P. Castro, 7 & 26 & - & - \\
\hline M. quadrivalvis var. leptocarpa (DC.) Barneby & Areia, PB (BE) & E.C.X.R. Santos, 5 & 52 & - & - \\
\hline M. sensitiva $\mathrm{L}$. & Serraria, PB (BE) & E.C.X.R. Santos, 9 & 26 & 26 & DN11 \\
\hline Mimosa setosa var. paludosa (Benth.) Barneby & Paulista, PE (MA) & L.P. Felix, 13.183 & 26 & 26,52 & DN11 \\
\hline M. somnians Humb \& Bampl ex Willd. & Areia, PB (BE) & E.M. Almeida, 96 & 52 & 26 & DN11 \\
\hline Mimosa somnians Humb \& Bampl ex Willd. & Areia, PB (BE) & E.C.X.R. Santos, 3 & 52 & 26 & - \\
\hline M. tenuiflora (Willd.) Poir. & Areia, PB (BE) & E.C.X.R. Santos, 2 & 26 & 26 & DN11 \\
\hline M. ulbrichiana Harms & Areia, PB (BE) & L.P. Felix, 13.134 & 26 & - & - \\
\hline Parkia pendula (Willd.) Walp. & Goiana, PE (MA) & L.P. Felix, S/N & 26 & 22 & BK07 \\
\hline Piptadenia viridiflora (Kunth.) Benth. & Arara, PB (CA) & E.C.X.R. Santos, 14 & 26 & & - \\
\hline
\end{tabular}

Sources: AT48 = Atchison, 1948; B74 = Bandel, 1974; BK07 = Barella and Karsburg, 2007; DN11 = Dahmer et al., 2011; M09 = Mata, 2009; O10 = Ortolani et al., 2010. Acronyms for the Brazilian States: AM=Amazonas; BA = Bahia; PB = Paraíba; $\mathrm{PE}=$ Pernambuco. Biomes: $\mathrm{AM}^{*}=$ Amazônia; $\mathrm{BE}=$ Brejo de altitude; $\mathrm{CA}=$ Caatinga; $\mathrm{MA}=$ Mata Atlântica. 
We undertook an initial survey of the chromosome numbers compiled in established chromosome number indices, in addition to referrals to the original publications, in order to gather basic information about the chromosome number variability within the subfamily as a whole. These data were then organized into a general table of chromosome numbers (Table 2), which was used to elaborate another list demonstrating the haploid chromosome numbers of each genus in decreasing order of their frequency (Table 3 ) and indicating the most probable basic chromosome numbers. These basic numbers generally corresponded to the most frequent haploid number of the genus or to those that most parsimoniously explained numerical relationships with related genera (Guerra, 2000). Thus, the taxa were organized into tribes according to the taxonomic treatment adopted by Queiroz (2009) (Table 2).

For karyological analyses, the root tips were pretreated with $2 \mathrm{mM} 8$-hydroxyquinoline for $20 \mathrm{~h}$, fixed in 3:1 Carnoy fixative (absolute ethanol/glacial acetic acid) for 3 to $24 \mathrm{~h}$ at room temperature, and stored at $-20^{\circ} \mathrm{C}$ in the fixing agent for subsequent analysis. To prepare the slides, the root tips were hydrolyzed in $5 \mathrm{~N} \mathrm{HCl}$ for $20 \mathrm{~min}$ at room temperature, squashed in $45 \%$ acetic acid, frozen in liquid nitrogen (to remove the coverslip), air dried, and stained conventionally with Giemsa (Guerra, 1983). The material was photographed using an Olympus BX41 microscope fitted with an Olympus D-54 digital camera.

\section{RESULTS}

All the species analyzed had semi-reticulated interphase nuclei, with condensed chromatin-forming chromocenters with irregular outlines (Figure 1A). Early condensing segments were observed in the proximal regions of the chromosome arms during prophase Figures 1J, $2 \mathrm{~F}$ ). The chromosome numbers varied from $2 n=16$ in Calliandra depauperata, Calliandra leptopoda, and Calliandra portoricensis to $2 n=78$ in Mimosa campicola, while chromosome sizes varied from $0.70 \mu \mathrm{m}$ in M. campicola to $2.57 \mu \mathrm{m}$ in Mimosa quadrivalvis var. leptocarpa (Figures 2D,H). The karyotypes were relatively symmetrical, with a predominance of meta- to submetacentric chromosomes; satellites were observed in Mimosa paraibana (Figure 2F), $M$. quadrivalvis (Figure 2H), and Mimosa tenuiflora (Figure 2L). In at least 2 species, Piptadenia viridiflora (Figure 2P) and Parkia pendula (Figure 2O), 2 pairs of acrocentric chromosomes lent an accentuated bimodality to the karyotypes. A synthesis of the principal karyotypic characteristics of the species is presented below.

In the tribe Acacieae, Senegalia bahiensis (Figure 1B), Senegalia riparia (Figure 1C), and Senegalia tenuifolia (Figure 1D) had $2 n=26$, while Vachellia farnesiana had $2 n=52$ (Figure 1E). The chromosomes were small, with the smallest chromosomes of $V$. farnesiana measuring $0.92 \mu \mathrm{m}$, and the largest chromosomes of $S$. riparia measuring $2.36 \mu \mathrm{m}$.

In the tribe Ingeae, Abarema filamentosa (Figure 1F) and a population of $C$. depauperata from Morro do Chapéu (Figure $1 \mathrm{H}$ ) were observed to have $2 n=26$ and chromosomes measuring from 1.02 to $1.90 \mu \mathrm{m}$. The 2 other species of Calliandra (C. leptopoda (Figure 1I) and C.portoricensis) (Figure 1J), as well as a population of $C$. depauperata (Figure 1H) from Santa Maria da Boa Vista, had karyotypes of $2 n=16$. In the genus Inga, I. edulis (Figure $1 \mathrm{O}$ ) and I. cinnamomea showed $2 n=26$ (Figure $1 \mathrm{~N}$ ) (the latter species being represented by 2 different populations from the states of Pernambuco and Amazonas). The number $2 n=26$ was also observed in Enterolobium contortisiliquum (Figure 1M). On the other hand, the only population of Chloroleucon sp (from the municipality of Serraria, Paraíba State) was tetraploid, with $2 n=52$, and had small chromosomes measuring from 0.78 to $1.14 \mu \mathrm{m}$ (Figure 1L). 


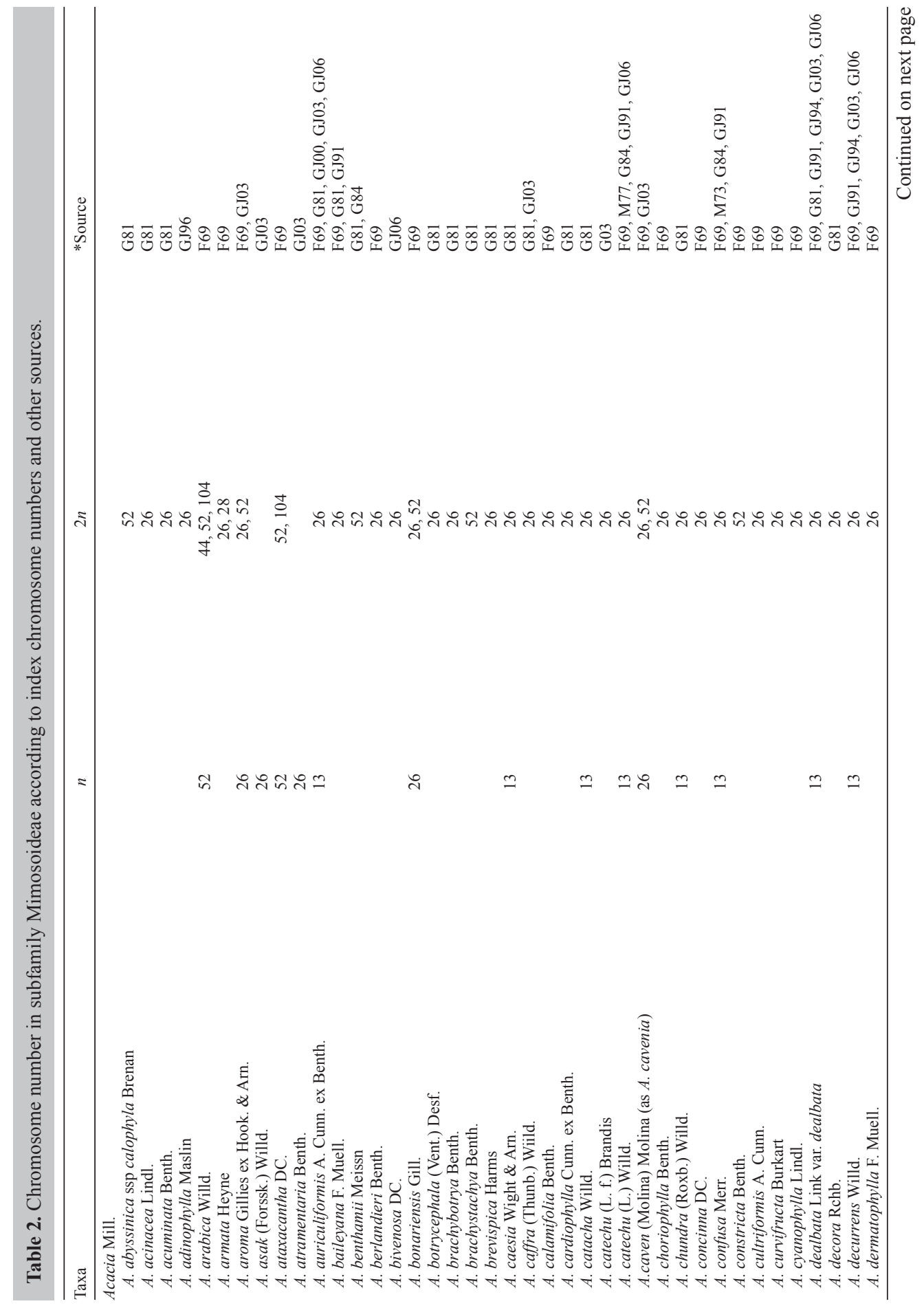


E.C.X.R. Santos et al.

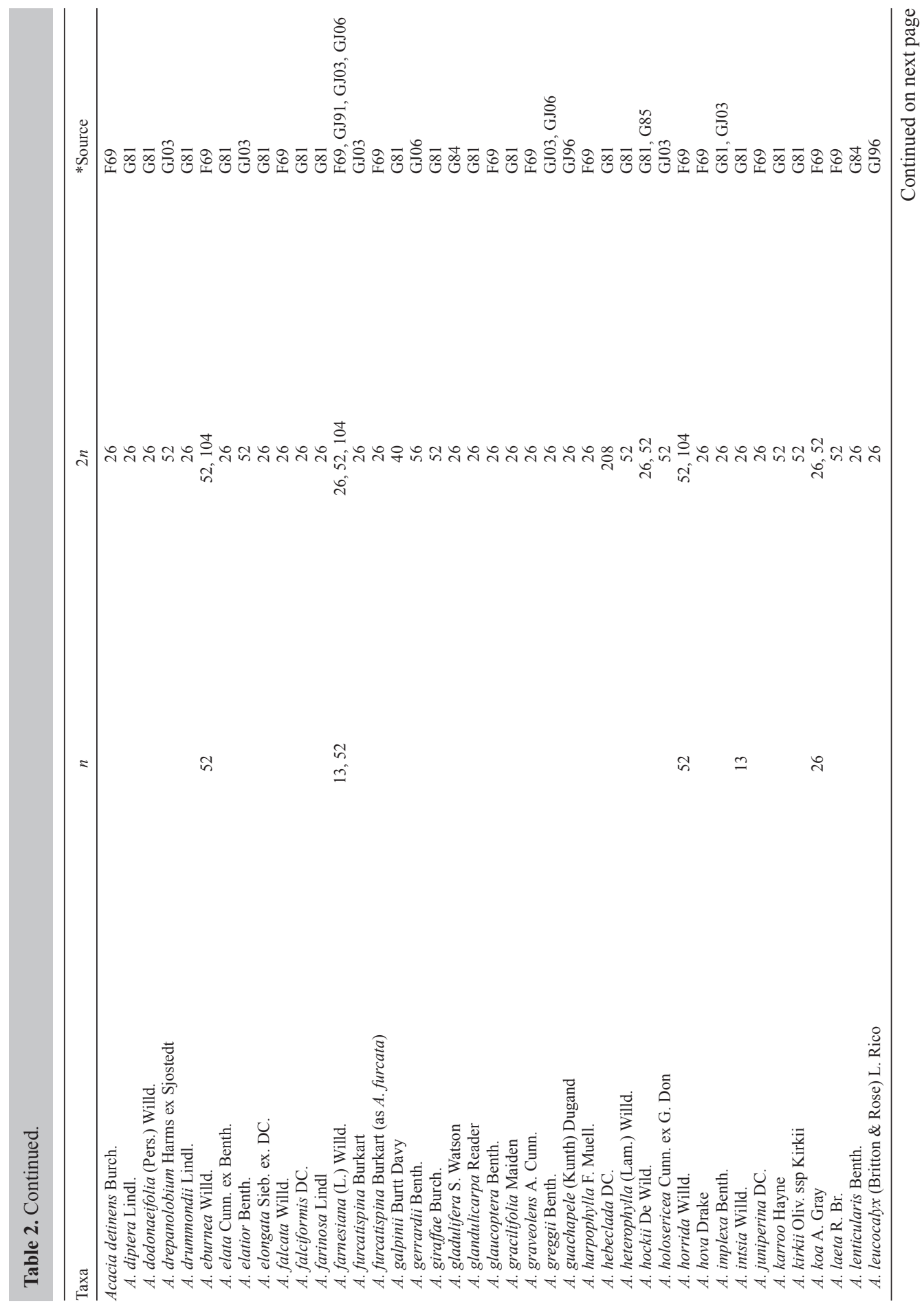

Genetics and Molecular Research 11 (3): 2451-2475 (2012) 


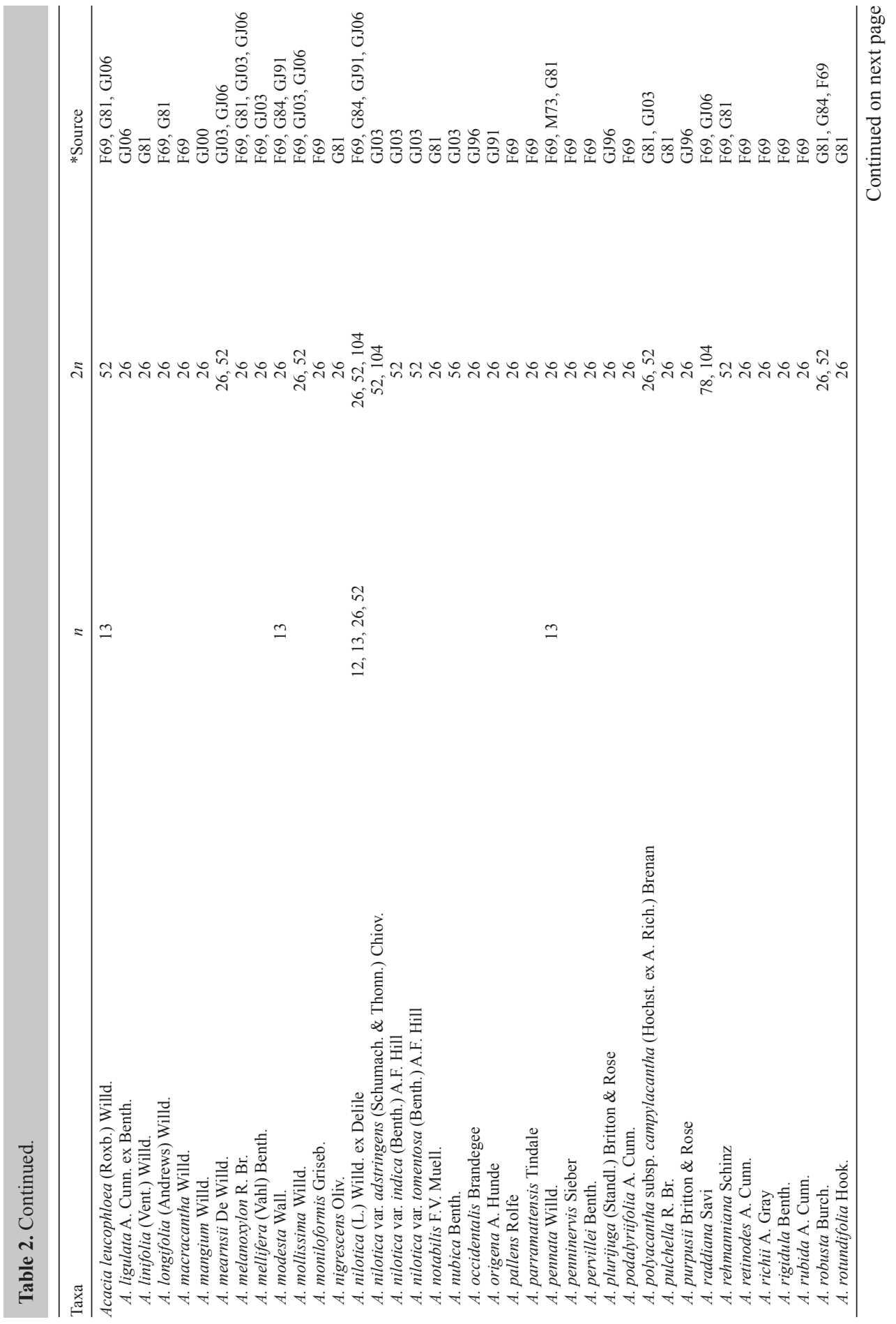


E.C.X.R. Santos et al.

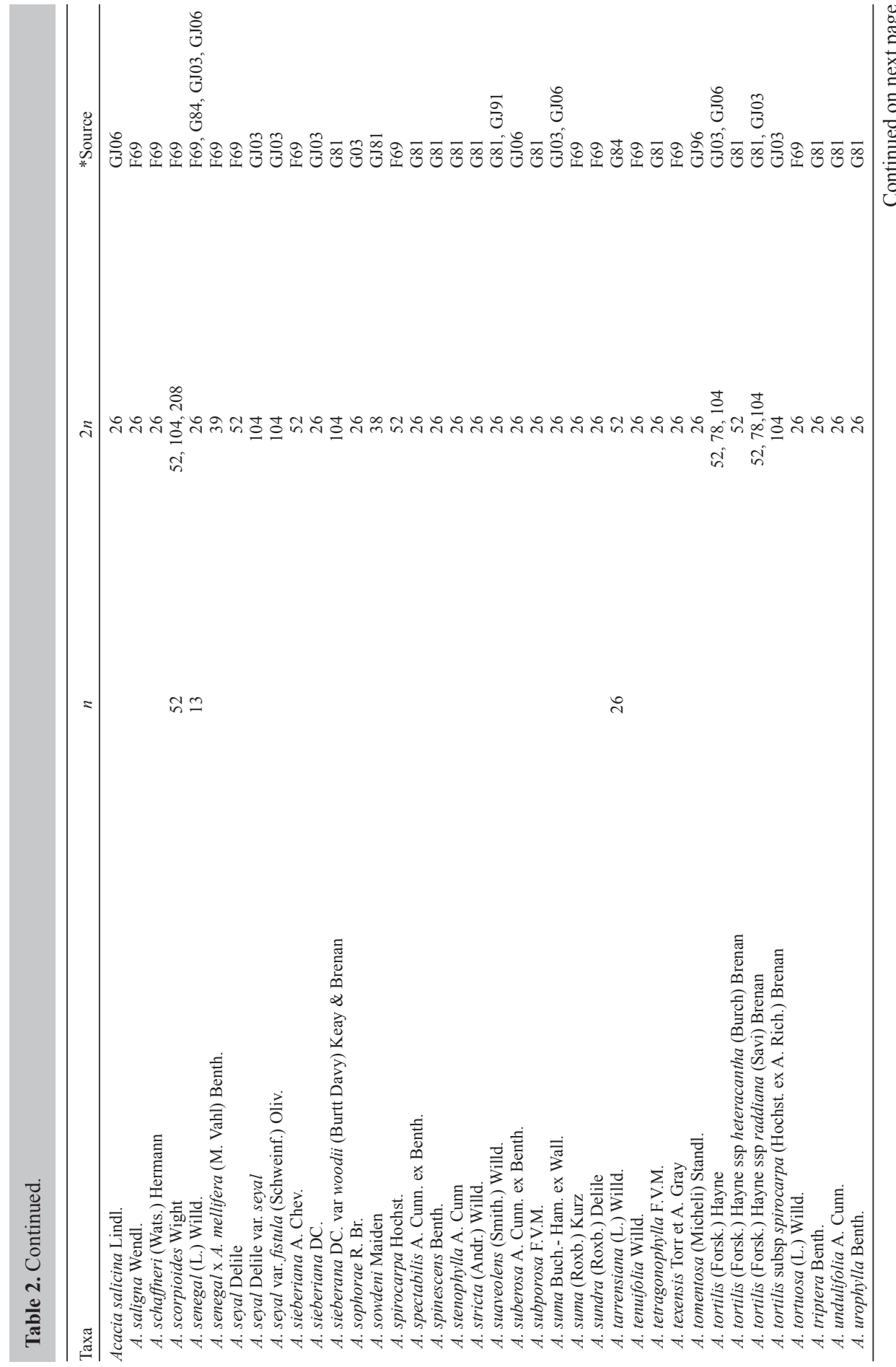




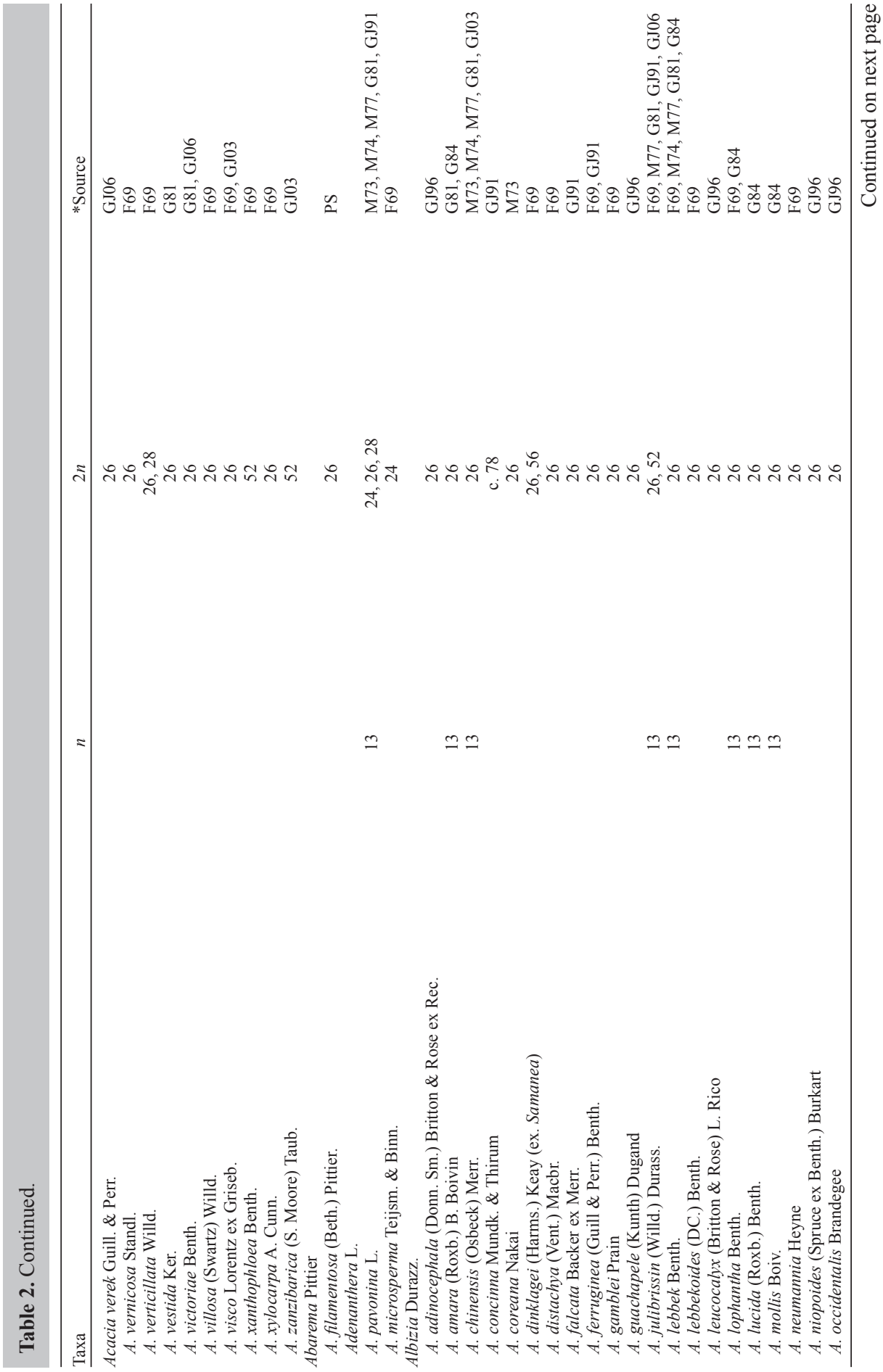


E.C.X.R. Santos et al.

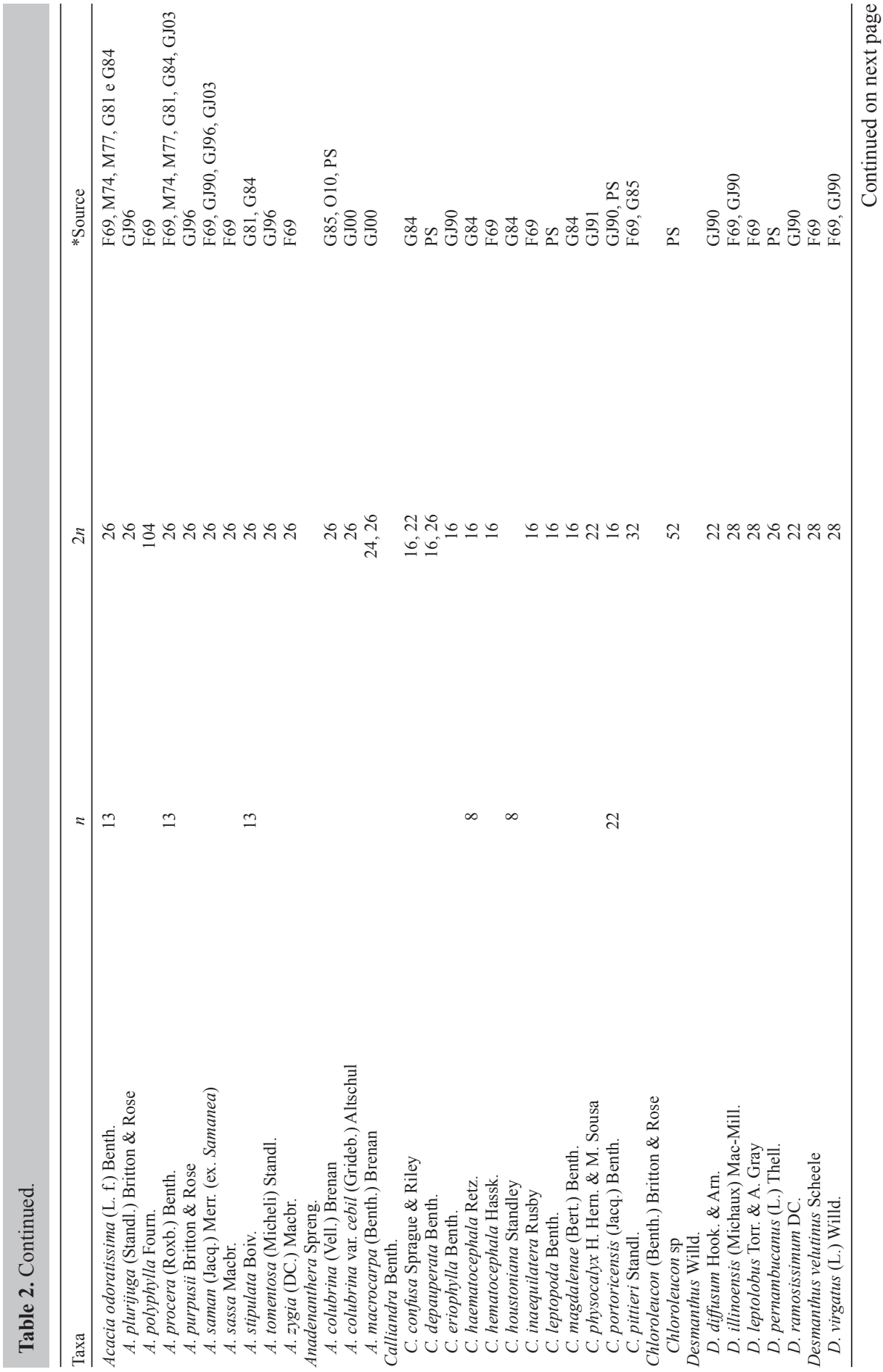

Genetics and Molecular Research 11 (3): 2451-2475 (2012) 


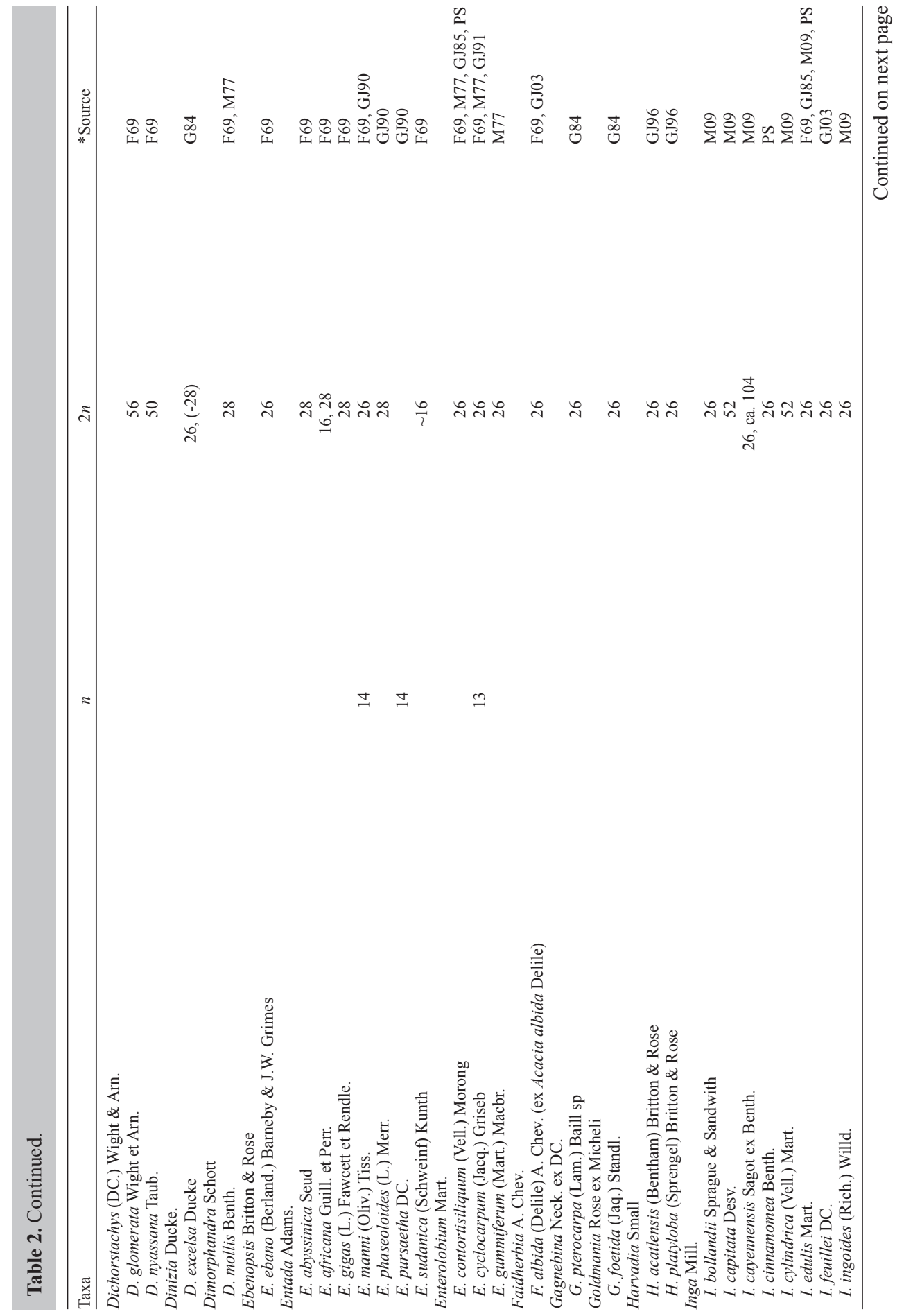


E.C.X.R. Santos et al.

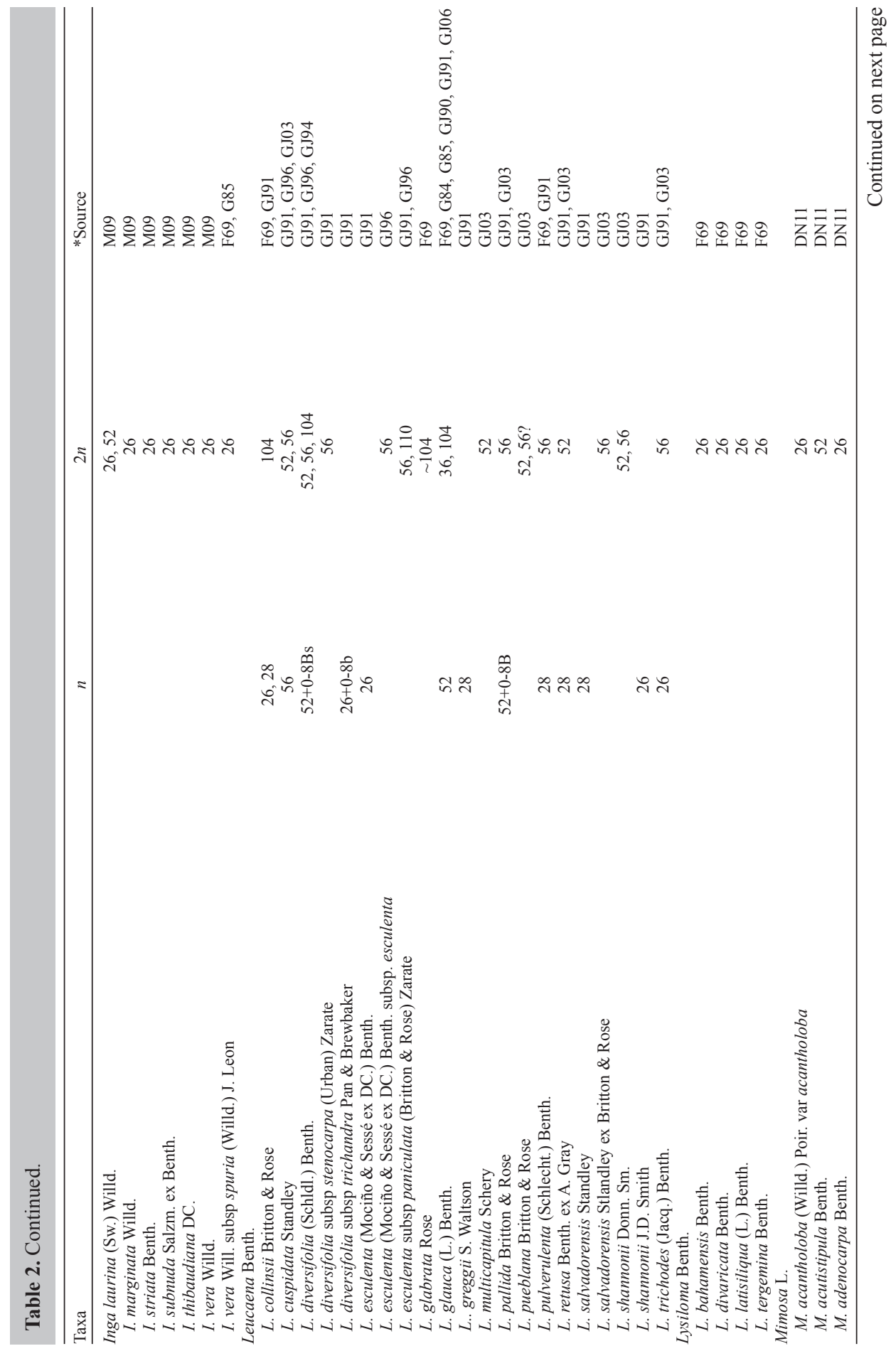


Chromosome variation in Leguminoseae - Mimosoideae

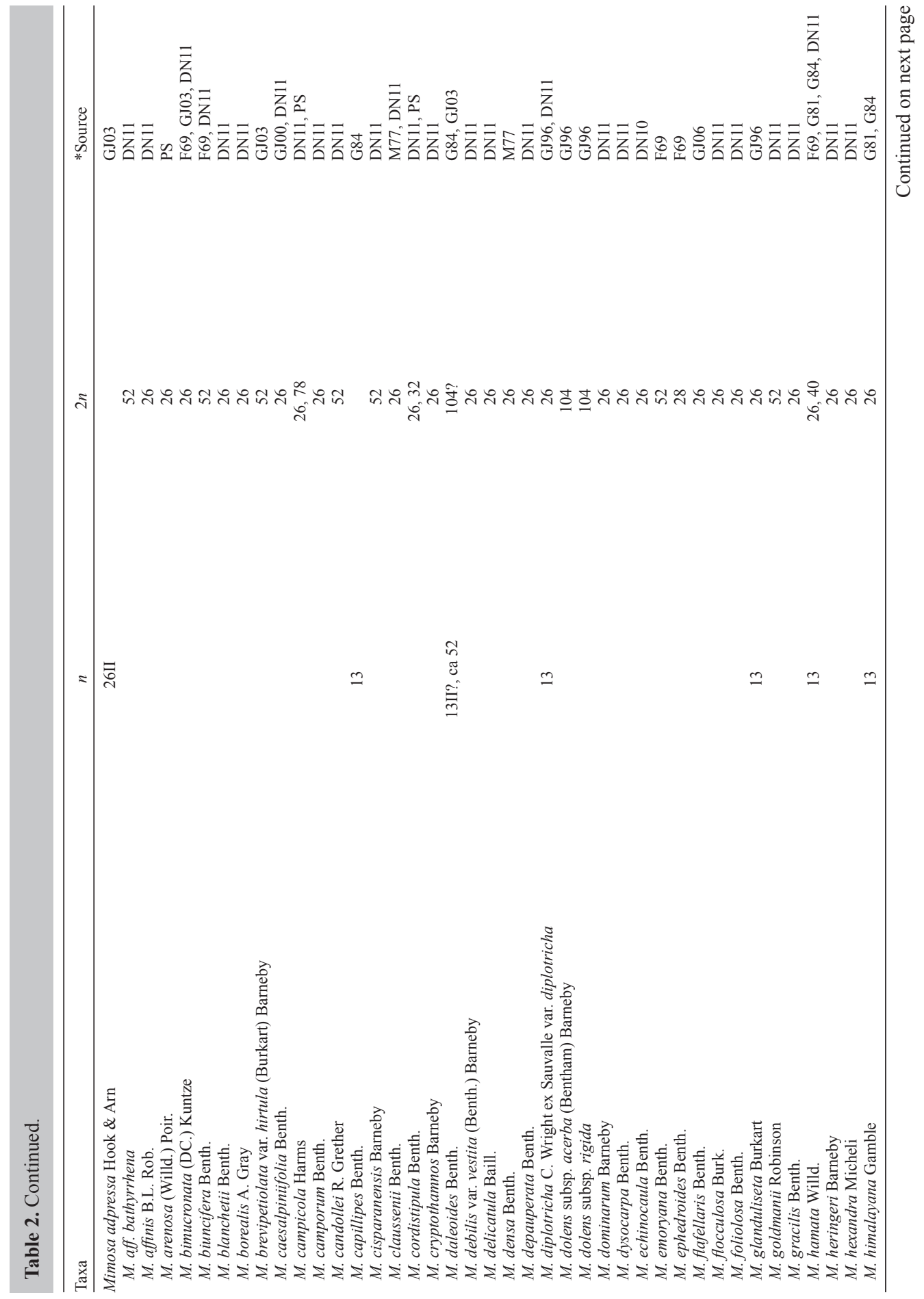

Genetics and Molecular Research 11 (3): 2451-2475 (2012) 


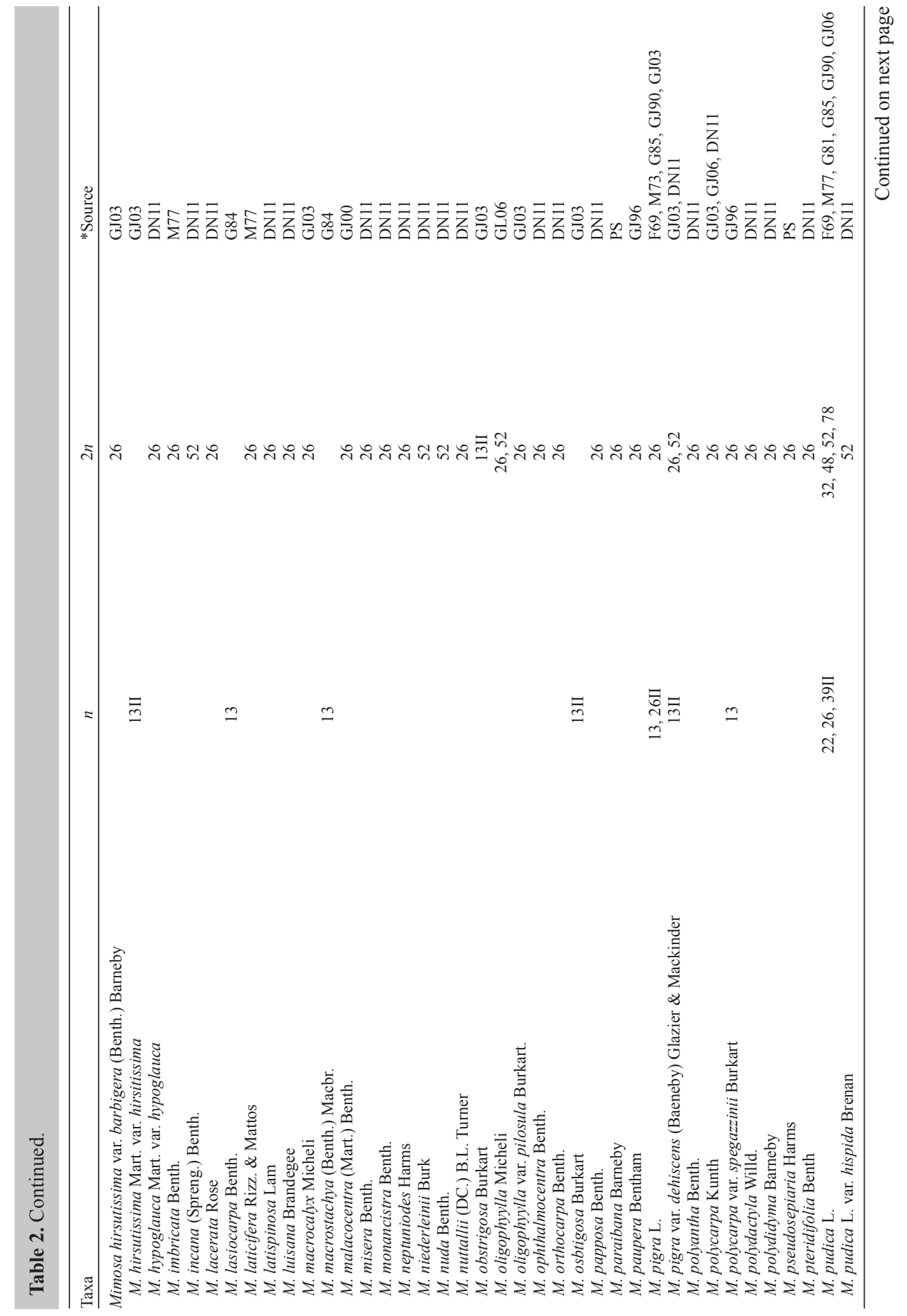




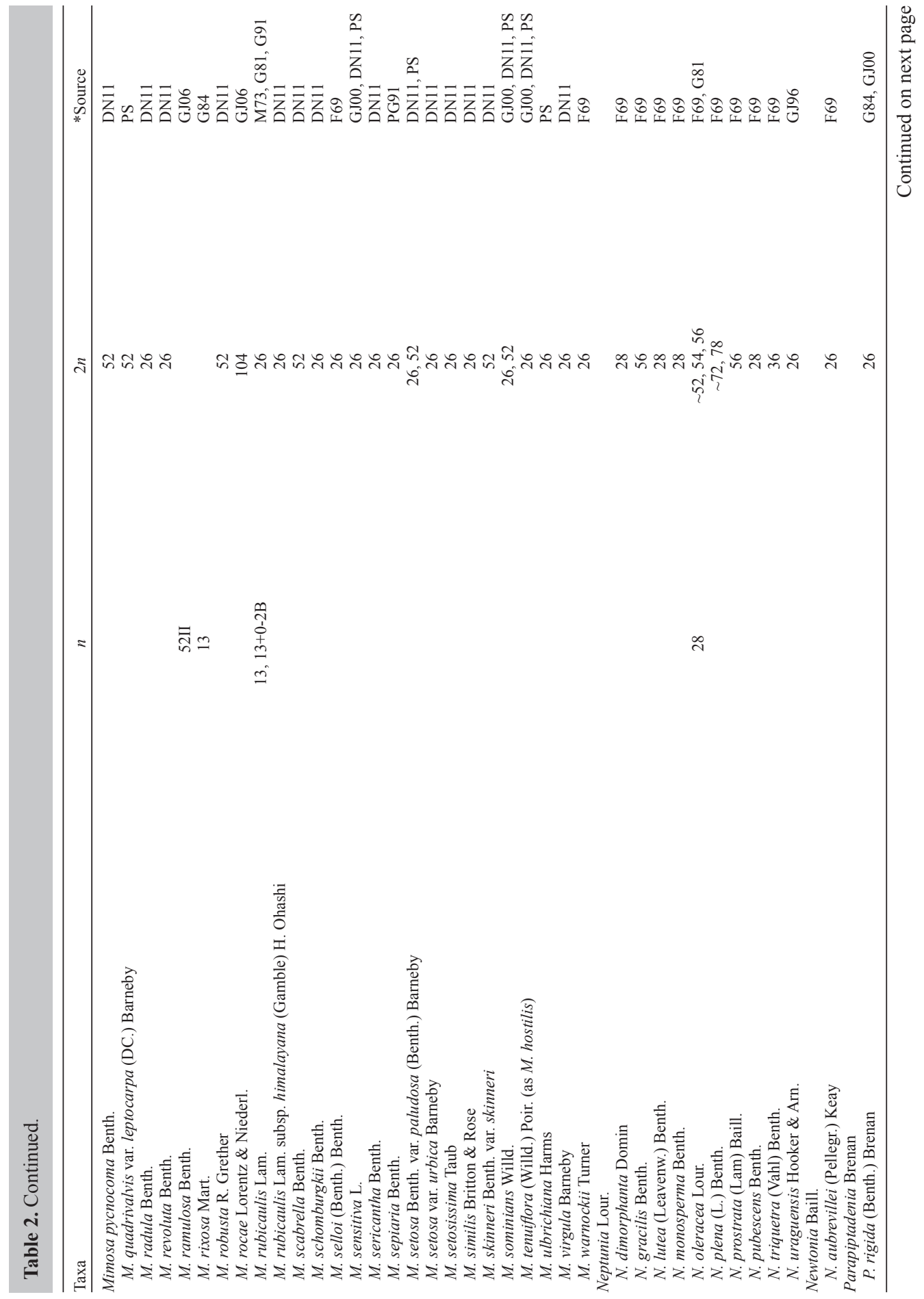


E.C.X.R. Santos et al.

2466

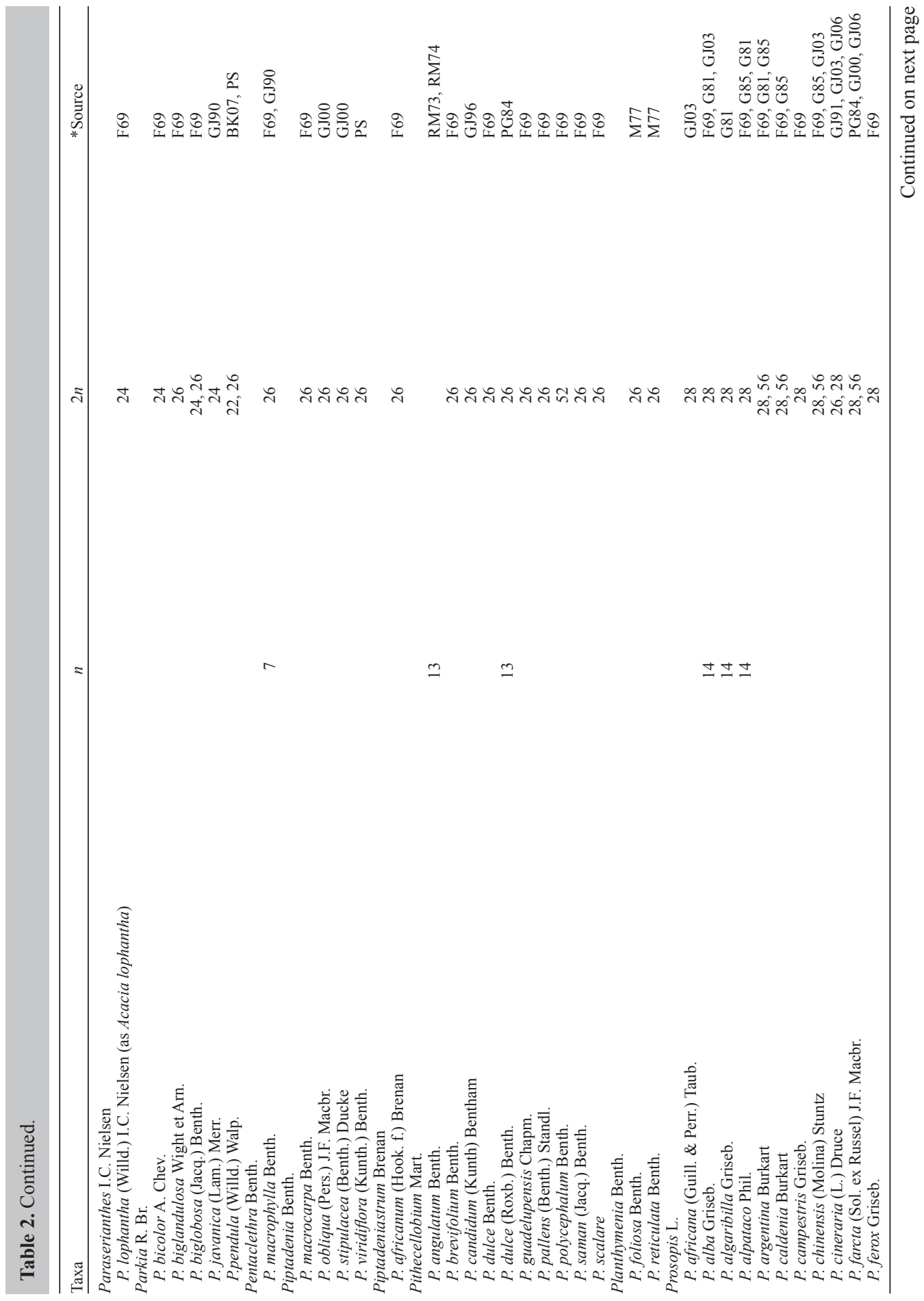

Genetics and Molecular Research 11 (3): 2451-2475 (2012)

CFUNPEC-RP www.funpecrp.com.br 


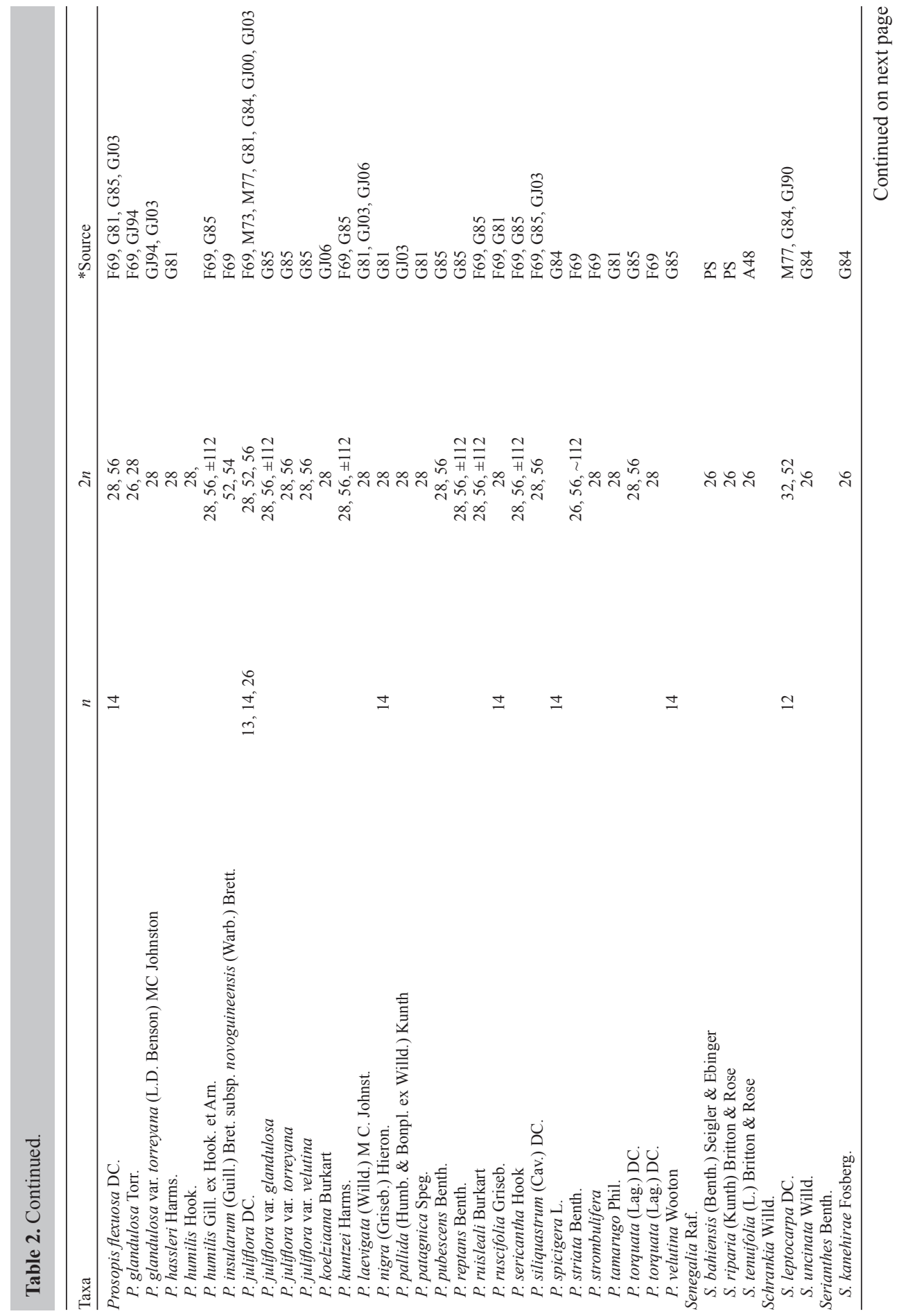


E.C.X.R. Santos et al.

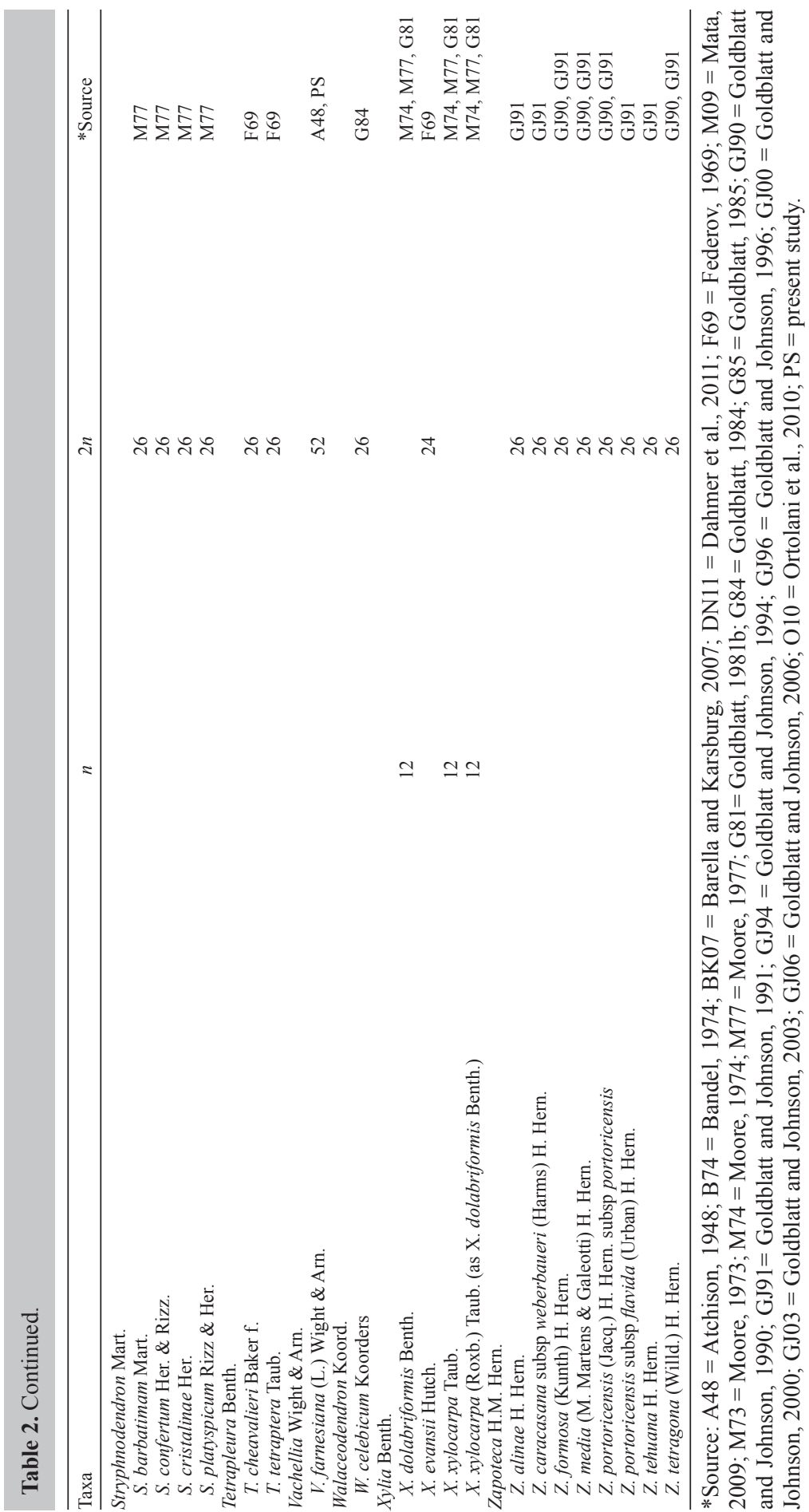




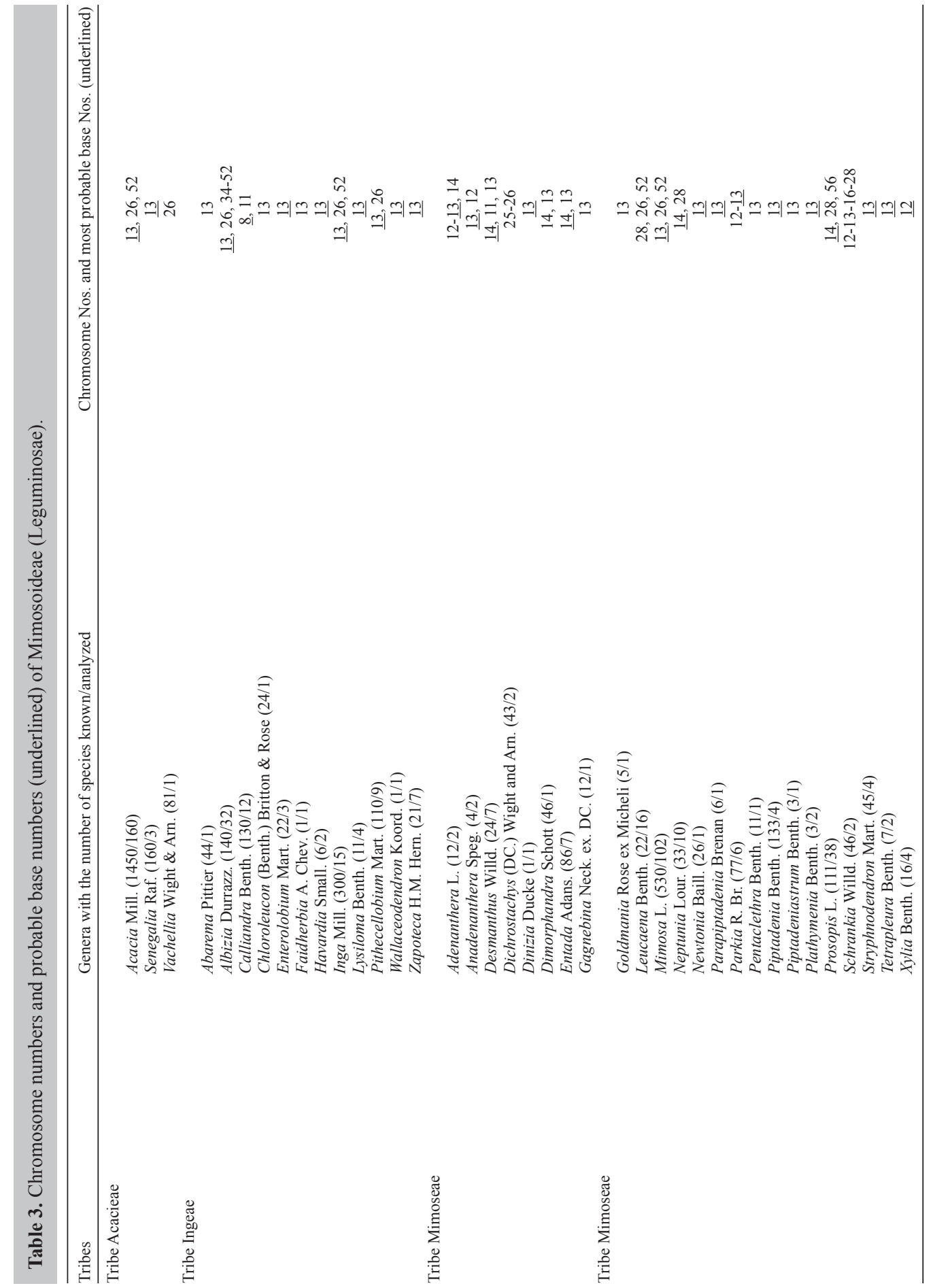




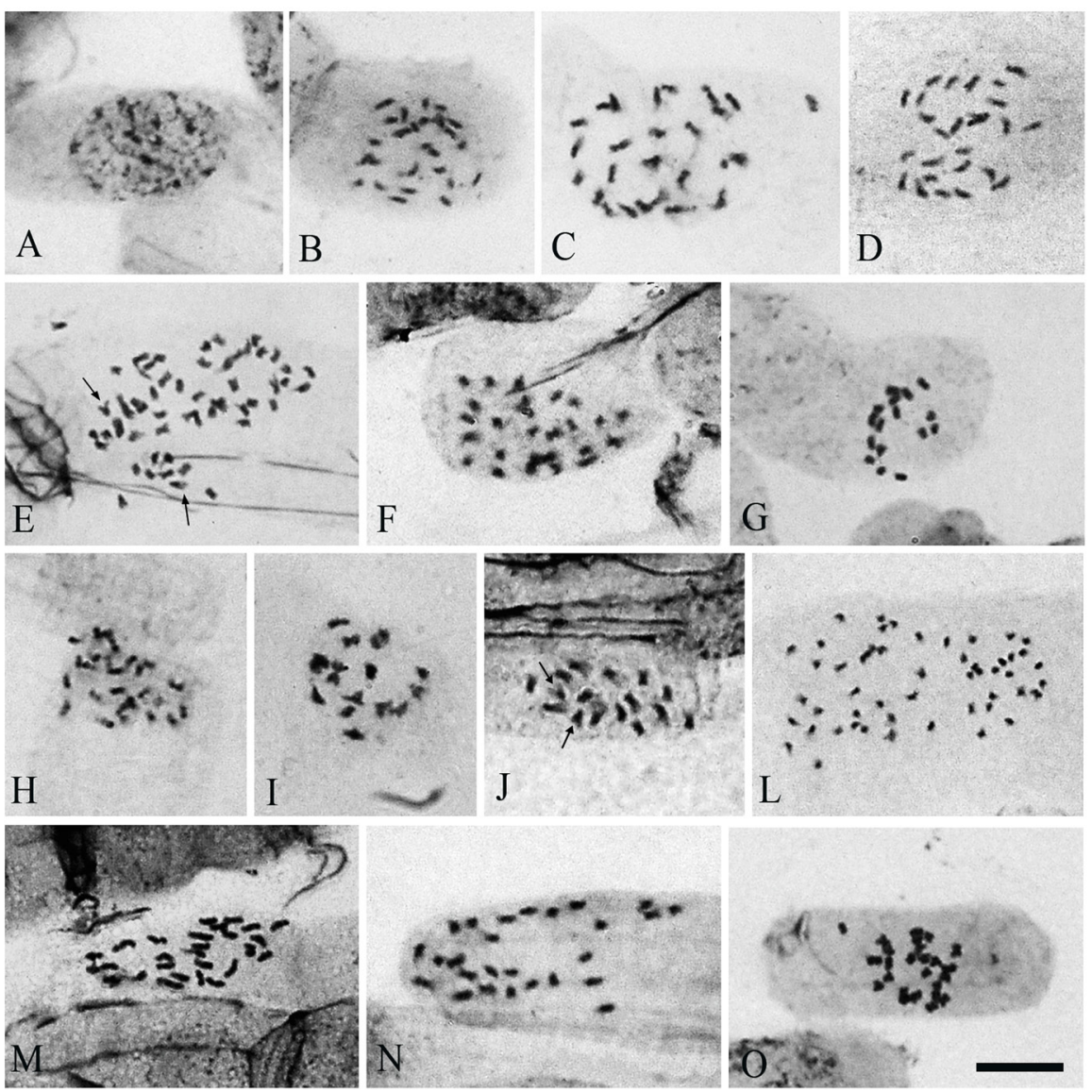

Figure 1. Chromosome complements and interphase nucleus of Leguminosae-Mimosoideae species of Acacieae and Ingeae tribes. A. Semi-reticulated interphase nucleus of Senegalia riparia; B-D. Senegalia species with $2 n=$ 26. S. bahiensis (B); S. riparia $(\mathbf{C}) ;$ S. tenuifolia (D); E. Vachellia farnesiana $(2 n=52) ; \mathbf{F}$. Abarema filamentosa $(2 n$ $=26)$; G. Calliandra depauperata $(2 n=16) ;$ H. C. depauperata $(2 n=26) ; \mathbf{I}$. C. leptopoda; J. C. portoricensis $(2 n$ $=16) ; \mathbf{L}$. Chloroleucon sp $(2 n=52) ;$ M. Enterolobium contortisiliquum $(2 n=26) ; \mathbf{N}$. Inga cinnamomea $(2 n=26)$; O. I. edulis $(2 n=26)$. Arrows in $\mathbf{E}$ and $\mathbf{J}$ indicate acrocentric chromosomes. Bar $=10 \mu \mathrm{m}$.

For the tribe Mimoseae, a single population of Anadenanthera colubrina (Figure 2A) from Caruaru, Pernambuco State, and 2 populations of Desmanthus pernambucanus (Figure 2B) from the states of Paraíba and Bahia, showed $2 n=26$. The chromosome numbers for the genus Mimosa were more variable, with $2 n=26$ in M. arenosa (Figure 2C), $M$. paraibana (Figure 2F), M. pseudosepiaria (Figure 2G), M. sensitiva (Figure 2I), M. tenuiflora (Figure 2L), M. ulbrichiana (Figure 2M), and M. setosa var. paludosa (Figure 2N); M. cordistipula had $2 n=32$ (Figure 2E), while 2 populations of M. campicola (Figure 2D) had $2 n=78$ and M. quadrivalvis var. leptocarpa (Figure 2H) and M. somnians (Figure 2J) had $2 n=52$. On the other hand, P. pendula (Figure 2O) and P. viridiflora (Figure 2P) were diploids with $2 n=26$. 


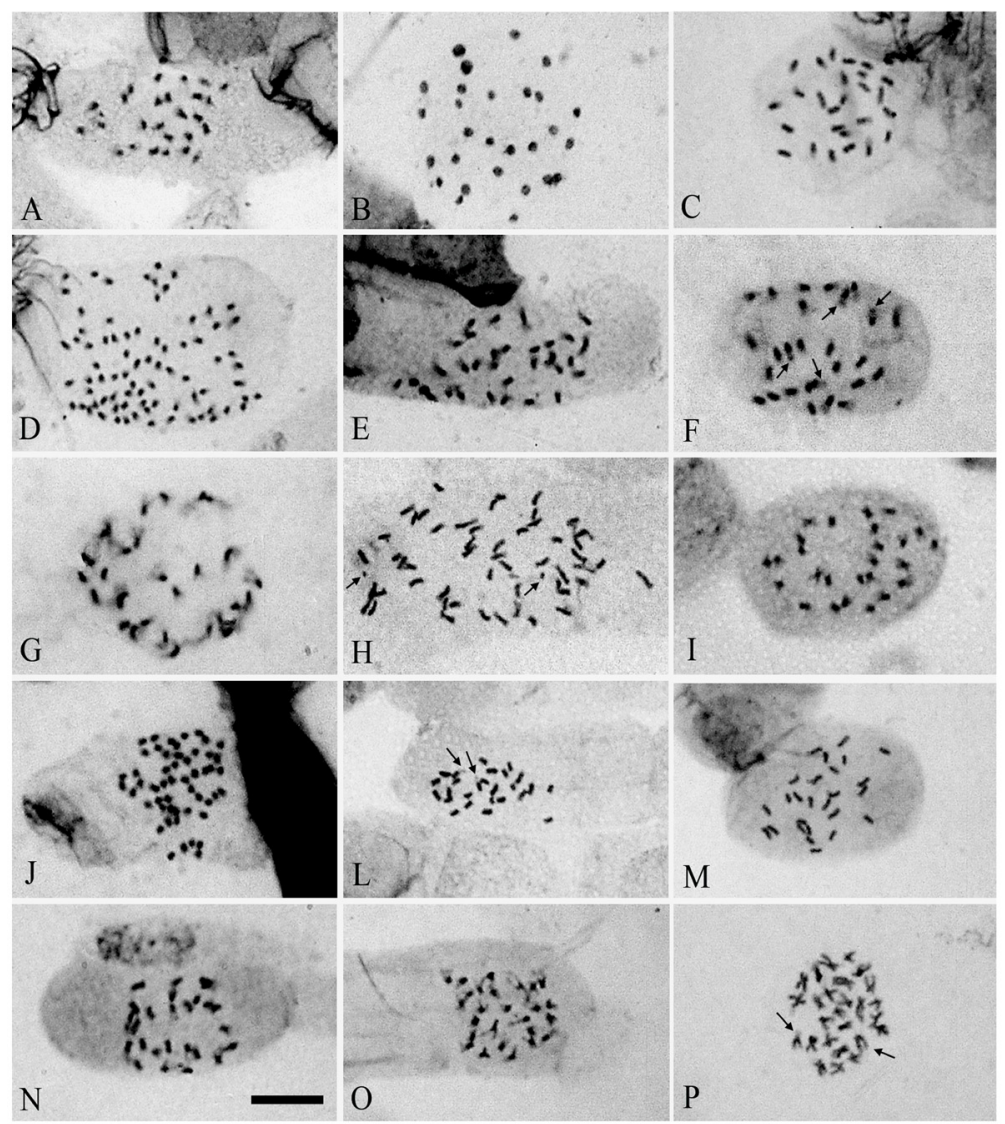

Figure 2. Chromosome complement of Leguminosae-Mimosoideae of the Mimoseae tribe. A-C. Species with $2 n$ =26. A. Anadenandera columbrina; B. Desmathus pernambucanus; C. Mimosa aremosa; D. M. campicola $(2 n=$ $78)$; E. M. cordistipula $(2 n=32)$; F. M. paraibana $(2 n=26)$; G. M. pseudosepiaria $(2 n=26)$; H. M. quadrivalvis var. leptocarpa $(2 n=52) ;$ I. M. sensitiva $(2 n=26) ;$ J. M. somnians $(2 n=52)$; L. M. tenuiflora; M. M. ulbrichiana; N. Mimosa sp. O. Parkia pendula; P. Piptadenia viridiflora; all showing $2 n=26$. Arrows in $\mathbf{F}, \mathbf{H}$ and $\mathbf{L}$ indicate satellited chromosomes and in $\mathbf{P}$ indicate acrocentric chromosomes. Bar $=10 \mu \mathrm{m}$.

\section{DISCUSSION}

The subfamily Mimosoideae comprises principally tropical and subtropical representatives of the American and African continents (Queiroz, 2009). Karyological records have been published for approximately 460 species (approximately 17\% of the total number of species in the subfamily), and in the Leguminosae family, Mimosoideae is the least studied group in terms of karyological characteristics. Taxa from tropical regions have generally been less intensively studied cytologically than those from temperate regions. In addition to the generally neotropical distributions of the Leguminosae-Mimosoideae, the small sizes of their chromosomes and the apparent stability of their chromosome numbers present unfavorable conditions for more extensive chromosomal analyses. Thus far, no reports have been published on the 
chromosome counts for 17 of the 27 species analyzed in the present study; additionally, we acquired the chromosome counts for the genus Chloroleucon for the first time. From previously published reports, we confirmed the counts of $2 n=26$ for $S$. tenuifolia, E. contortisiliquum, $I$. edulis, A. colubrina, M. cordistipula, $M$. sensitiva, $M$. setosa var. paludosa, and M. tenuiflora, and $2 n=52$ for $M$. somnians and $V$. farnesiana. The previous counts of $2 n=22$ for $P$. pendula (Barella and Karsburg, 2007), $2 n=26$ for M. campicola, M. cordistipula, and M. somnians and $2 n=52$ for M. setosa var. paludosa (Dahmer et al., 2011) were not confirmed. We obtained $2 n$ $=26$ for P. pendula and M. setosa var. paludosa; $2 n=32$, for a population of M. cordistipula; $2 n=78$, for 2 populations of M. campicola, and $2 n=52$, for 2 other populations of M. somnians. The values obtained for the latter 2 groups of populations appear to be related to the occurrence of polyploidy, the karyotypic evolutionary process believed to be most active in the subfamily (Goldblatt, 1981a). Disploidy also seems to have an important role in the evolution of this group, and in some cases, may explain the discrepancies between the samples analyzed in this study and in the subfamily as a whole (see discussion below).

The importance of polyploidy to the evolution of the subfamily Mimosoideae can be appreciated by a study by Dahmer et al. (2011) wherein variations were observed in the chromosome numbers for a sample of 83 principally neotropical species of the genus Mimosa. These authors observed that $26 \%$ of the species analyzed were polyploids and that at least 3 of them exhibited intraspecific polyploidy. A similar evolutionary pattern of polyploidy was also observed in other South America species of Mimosa (Seijo and Fernández, 2001) and Leucaena (Boff and Schifino-Wittmann, 2003). A total of 13 species of the genus Inga from northeastern Brazil were analyzed, and 4 were found to be polyploids ( 2 of them showing intraspecific polyploidy; Mata, 2009, unpublished data). The divergence of the counts observed in our study from those previously published confirms the occurrence of intraspecific polyploidy for 3 of the species analyzed. On the other hand, the counts of $2 n=32$ obtained for $M$. cordistipula and $2 n=26$ for P. pendula (representing $7.4 \%$ of the species analyzed) indicate that disploidy may have had a very important role in the karyotypic evolution of the Mimosoideae from northeastern Brazil. On the other hand, analyses of previously observed numerical variations (Table 2) revealed only rare cases of intraspecific disploidy in the subfamily $(1.46 \%$ of the species listed), which may have been a consequence of insufficient population sampling (commonly observed in older cytogenetic analyses) or counting errors (see, for example, Merxmüller, 1970).

Although the majority of the genera of this subfamily clearly show that their karyotypic evolution was regulated by numerous cycles of polyploidy with a basic number $x=13$, various genera may have diverged from this principal lineage. In Leucaena, for example, there are paleopolyploid species with $2 n=52$ and 58, suggesting that there may have been 2 basic numbers-1 originating through disploidy from an ancestral stock with $x_{2}=26$ (Boff and Schifino-Wittmann, 2003). Genera, such as Desmanthus, Entada, and Prosopis (Table 2), have the basic number $x=14$, which apparently resulted from ascending disploidy from a principal lineage with $x=13$. On the other hand, almost all the species of the genus Calliandra with known chromosome numbers appear to have been derived from a distinct karyotypic lineage with $x=8$ (Tables 2 and 3). Interestingly, 1 of the 3 species analyzed in the present study, namely, $C$. depauperata, had $2 n=26$ in 1 of the 2 populations studied-a number that is difficult to explain-as was the case in previously reported counts for the genus, such as $2 n=16,22$ for C. confusa (Goldblatt, 1981a) and $2 n=22$ for C. physicocalyx (Hernández and Sousa, 1988). 
On the whole, these counts indicate that more than 1 basic number may be involved in the karyotypic diversification of the genus Calliandra. The occurrence of $n=7$ in various species of the genus Cercis and $n=14$ in Bauhinia from the tribe Cercideae (which is considered a sister group of the other Leguminosae) (Wojciechowski et al., 2004), suggests a primary basic number of $x_{1}=7$ for the family as a whole (Goldblatt, 1981a). If this was true, Bauhinia would have originated by direct polyploidy from the ancestral stock with $x=7$, while the species of Calliandra with $x=8$ probably represent an old lineage derived from ascendant disploidy. On the other hand, a majority of the genera of Mimosoideae paleopolyploids would have been formed by descending disploidy from an ancestral paleopolyploid with $x=14$ (Khatoon and Ali, 2006).

Polyploidy constitutes one of the principal mechanisms of speciation in plants, and it is estimated that more than $70 \%$ of all angiosperms are polyploids (Stebbins, 1971; Leitch and Bennett, 1997). Polyploids have been reported to have good ability to adapt to unstable environments and are most common in ecosystems that experience severe climatic stress, such as those in the arctic or glacial regions (Brochmann et al., 2004; Parisod et al., 2010) or in disturbed environments (Stebbins, 1971). The "Caatinga" biome covers about $70 \%$ of northeastern Brazil and is characterized by extreme water-related stress conditions and generally thin, rocky, and eroded soils. Some taxonomic groups, such as orchids of the genera Oncidium and Epidendrum (Felix and Guerra, 2000, 2010), and Hoffmannseggella (Yamagishi-Costa and Forni-Martins, 2009) have a strong tendency to form polyploids in environments that experience extreme conditions of abiotic stress. Other taxonomic groups, however, such as the families Convolvulaceae (Pitrez et al., 2008) and Amaryllidaceae (Felix et al., 2011), show no apparent correlation between polyploidy and environmental stress. The evolution of plant groups by the duplication of their genomes is generally rarer in tropical regions than in temperate zones, where environmental fluctuations are more frequent and are conducive to the formation of non-reduced gametes (Leitch and Bennett, 1997). This might explain the low frequency of reported polyploid species for the subfamily Mimosoideae and for other plant families that occur in tropical regions. The present study revealed that polyploid species occur in both "Caatinga" environments and altitudinal forests (a relatively stable meso-environment). Similarly, Dahmer et al. (2011) reported that some specimens from "Cerrado" (savanna), Atlantic forest, and "Caatinga" regions demonstrated no apparent correlation between polyploidy and high-stress environments. A correlation between polyploidy and abiotic stress has been demonstrated only in rare cases, and therefore, this phenomenon cannot be considered generic (reviewed by Parisod et al., 2010).

One of the explanations offered for the predominance of polyploidy, particularly allopolyploidy, as a predominant evolutionary process in angiosperms is the acquisition of evolutionary advantages associated with the formidable reorganization of the genome induced by polysomic inheritance. In these cases, polyploid plants that were established in disturbed environments could more easily colonize new and different habitats (Brochmann et al., 2004; Parisod et al., 2010). However, this process appears to have been stochastic for the subfamily Mimosoideae, recurring in diverse lineages and equally favoring polyploid populations in both stable and mesic environments (such as "Brejos de Altitude") and in unstable environments subject to climatic stress (such as the dryland "Caatinga"). Most genera of Mimosoideae that were formed from ancient paleopolyploid species with $x=13$ were apparently included in this process. Within the subfamily, the genus Calliandra, with $x=8$, was the only lineage that 
maintained a diploid level, and together with the genus Cercis (subfamily Caesalpinioideae), it represents one of the oldest diploid lineages related to an ancestral stock with $x=7$.

\title{
ACKNOWLEDGMENTS
}

\author{
Research supported by CNPq.
}

\section{REFERENCES}

Atchison E (1948). Studies in the Leguminosae. II. Cytogeography of Acacia (Tourn). L. Am. J. Bot. 35: 651-655.

Atchison E (1951). Studies in the Leguminosae VI. Chromosome number among tropical woody species. Am. J. Bot. 38: 538-554.

Bandel G (1974). Chromosome numbers and evolution in the Leguminosae. Caryologia 27: 17-32.

Barella APW and Karsburg IV (2007). Caracterização morfológica dos cromossomos mitóticos de Parkia pendula (Willd.) Benth ex Walp. e Dinizia excelsa Ducke (Fabaceae, Mimosoideae). Rev. Cienc. Agr.-Ambient. 5: 85-93.

Boff T and Schifino-Wittmann MT (2003). Segmental allopolyploidy and paleopolyploidy in species of Leucaena benth: evidence from meiotic behaviour analysis. Hereditas 138: 27-35.

Brochmann C, Brysting AK, Alsos IG, Borgen L, et al. (2004). Polyploidy in arctic plants. Biol. J. Linn. Soc. 82: 521-536.

Dahmer N, Simon MF, Schifino-Wittmann MT, Hughes CE, et al. (2011). Chromosome numbers in the genus Mimosa L.: cytotaxonomic and evolutionary implications. Plant Syst. Evol. 3: 211-220.

Federov AMA (1969). Chromosome Numbers of Flowering Plants. Komarov Botanical Institute, Leningrad.

Felix LP and Guerra M (2000). Cytogenetics and cytotaxonomy of some Brazilian species of cymbidiois orchids. Genet. Mol. Biol. 23: 957-978.

Felix LP and Guerra M (2010). Variation in chromosome number and basic number of subfamily Epidendroideae (Orchidaceae). Bot. J. Linn. Soc. 163: 234-278.

Felix WJP, Felix LP, Melo NF, Oliveira MBM, et al. (2011). Karyotype variability in species of the genus Zephyranthes Herb. (Amaryllidaceae-Hippeastreae). Plant. Syst. Evol. 294: 263-271.

Goldblatt P (1981a). Cytology and the Phylogeny of the Leguminosae. In: Advances in Legume Systematics, Part 1 (Polhill RM and Raven PM, eds.). Royal Botanic Gardens, Kew, 427-463.

Goldblatt P (1981b). Index to Plant Chromosome Numbers 1975-1978. Missouri Bot. Gard., St Louis.

Goldblatt P (1984). Index to Plant Chromosome Numbers 1979-1981. Missouri Bot. Gard., St Louis.

Goldblatt P (1985). Index to Plant Chromosome Numbers 1982-1983. Missouri Bot. Gard., St Louis.

Goldblatt P and Johnson DE (1990). Index to Plant Chromosome Numbers 1986-1987. Missouri Bot. Gard., St Louis.

Goldblatt P and Johnson DE (1991). Index to Plant Chromosome Numbers 1988-1989. Missouri Bot. Gard., St Louis.

Goldblatt P and Johnson DE (1994). Index to Plant Chromosome Numbers 1990-1991. Missouri Bot. Gard., St Louis.

Goldblatt P and Johnson DE (1996). Index to Plant Chromosome Numbers 1992-1993. Missouri Bot. Gard., St Louis.

Goldblatt P and Johnson DE (2000). Index to Plant Chromosome Numbers 1984-1985. Missouri Bot. Gard., St Louis.

Goldblatt P and Johnson DE (2003). Index to Plant Chromosome Numbers 1998-2000. Missouri Bot. Gard., St Louis.

Goldblatt P and Johnson DE (2006). Index to Plant Chromosome Numbers 2001-2003. Missouri Bot. Gard., St Louis.

Guerra M (1983). O uso do Giemsa na citogenética vegetal - comparação entre a coloração simples e o bandeamento. Cienc. Cult. 35: 190-193.

Guerra M (2000). Chromosome Number Variation and Evolution in Monocots. In: Monocots: Systematics and Evolution (Wilson KL and Morrison DA, eds.). CSRIRO, Melbourne, 127-136.

Hernández HM and Sousa M (1988). Two new species of Calliandra (Leguminosae: Mimosoideae) from southern Mexico. Syst. Bot. 13: 519-524.

Judd WS, Campbell CS, Kellogg EA, Stevens PF, et al. (2009). Sistemática Vegetal: Um Enfoque Filogenético. Artmed, Porto Alegre.

Khatoon S and Ali SI (2006). Chromosome Numbers and Polyploidy in the Legumes of Pakistan. Pak. J. Bot. 38: $935-945$. Leitch IJ and Bennett MD (1997). Polyploidy in angyosperms. Trends Plant Sci. 12: 470-476.

Luckow M (2005). Mimoseae. In: Legumes of the World (Lewis GP, Schrine BD, Mackinder BA and Lock M, eds.). Royal Botanic Gardens, Kew.

Mata MF (2009). O Gênero Inga (Leguminosae, Mimosoideae) no Nordeste do Brasil: Citogenética, Taxonomia e Tecnologia de Sementes. Doctoral thesis, Universidade Federal da Paraíba, UFPB, Areia.

Merxmüller H (1970). Provocation of biosystematics. Taxon 19: 140-145.

Genetics and Molecular Research 11 (3): 2451-2475 (2012)

CFUNPEC-RP www.funpecrp.com.br 
Moore RJ (1973). Index to plant chromosome number 1967-1971. Regnum Veg. 90: 1-539.

Moore RJ (1974). Index to plant chromosome number 1972. Regnum Veg. 91: 1-108.

Moore RJ (1977). Index to plant chromosome number 1973-1974. Regnum Veg. 91: 1-257.

Ortolani FA, Melloni MNG, Mariotto CFG and Moro JR (2010). Caracterização citogenética em Anadenanthera colubrina (Vell.) Brenan (Mimosoideae) e Guazuma ulmifolia Lam. (Sterculiaceae). Acta Bot. Bras. 24: 299-303.

Parisod C, Holderegger R and Brochmann C (2010). Evolutionary consequences of autopolyploidy. New Phytol. 186: 5-17.

Pitrez SR, Andrade LA, Alves LIF and Felix LP (2008). Karyology of some Convolvulaceae species occurring in NE Brazil inselbergs. Plant Syst. Evol. 276: 235-241.

Queiroz LP (2009). Leguminosas da Caatinga. Universidade Estadual de Feira de Santana, Feira de Santana.

Seijo G and Fernández A (2001). Chromosome numbers of some southernmost species of Mimosa L. (Leguminosae). Cytologia 66: 19-23.

Stebbins GL (1971). Chromosomal Evolution in Higher Plants. Edward Arnold, London.

Wojciechowski MF, Lavin M and Sanderson MJ (2004). A phylogeny of legumes (Leguminosae) based on analysis of the plastid matK gene resolves many well-supported subclades within the family. Am. J. Bot. 91: 1846-1862.

Yamagishi-Costa J and Forni-Martins ER (2009). Hybridization and polyploidy cytogenetic indications for Hoffmannseggella (Orchidaceae) species evolution. Int. J. Bot. 5: 93-99. 